\title{
Strategy for Combining Heat Treatment, Calcium Infiltration, and Biological Control to Reduce Postharvest Decay of 'Gala' Apples
}

\author{
William S. Conway \\ Horticultural Crops Quality Laboratory, Beltsville Agricultural Research \\ Center Agricultural Research Service, U.S. Department of Agriculture, \\ Beltsville, MD 20705
}

Wojciech J. Janisiewicz

Appalachian Fruit Research Station, Agricultural Research Service, U.S. Department of Agriculture, 45 Wiltshire Road, Kearneysville, WV 25430

Joshua D. Klein

Department of Field Crops, ARO, The Volcani Center, Bet Dagan 50250, Israel

Carl E. Sams

Department of Plant and Soil Sciences, The University of Tennessee, Knoxville, TN 37901

Additional index words. Malus $\times$ domestica, Penicillium expansum, Pseudomonas syringae, bacteria, $\mathrm{CaCl}_{2}$, fungi, pressure infiltration

\begin{abstract}
The viability of Penicillium expansum Link conidia in sporulating culture declined rapidly when exposed to $38{ }^{\circ} \mathrm{C}$, and when conidia were exposed to $38^{\circ} \mathrm{C}$ prior to inoculation of apple fruits (Malus $\times$ domestica Borkh.), the resulting lesions were smaller than those on fruit inoculated with nonheated conidia. ' $G$ ala' apples were heated after harvest $\left(38{ }^{\circ} \mathrm{C}\right.$ for 4 days), pressure infiltrated with a $2 \%$ solution of $\mathrm{CaCl}_{2}$, or treated with the antagonist Pseudomonas syringae van Hall, alone or in combinations to reduce postharvest decay caused by Penicillium expansum. After up to 6 months in storage at $1^{\circ} \mathrm{C}$, no decay lesions developed on fruit that were heated after inoculation with $P$. expansum, or any combination of $P$. expansum, antagonist, or $\mathrm{Ca}$. Parallel lots of heat-treated and nonheated fruit that were either infiltrated or not infiltrated with Ca were stored up to 6 months. They were then inoculated with $P$. expansum alone, or with the antagonist followed by $P$. expansum. Prior heat treatment did not influence lesion size. Calcium alone, the antagonist alone, and heat plus $\mathrm{Ca}$ all reduced the incidence of decay by $\approx 25 \%$, whereas heat plus the antagonist reduced it by $\mathbf{7 0 \%}$. Calcium plus the antagonist or Ca plus the antagonist and heat reduced decay incidence by $89 \%$ and $91 \%$, respectively. The integrated strategy of heat-treating fruit, followed by Ca infiltration and then treatment with an antagonist, may be a useful alternative to controlling postharvest decay with fungicides.
\end{abstract}

Fungicides, when properly used, offer a high level of control of postharvest pathogens in most cases. However, alternatives to chemical control are being sought because of the growing concern of consumers, either real or perceived, that chemical residues on the surface of fruit can create health problems, as well as the increasing resistance of many fungi to commonly used fungicides. The ultimate goal of the research is to use alternatives, either alone or in combination, to reduce our dependency on fungicides.

Received for publication 28 July 1998 . Accepted for publication 11 Dec. 1998. We thank George A. Brown, Craig S. Charron, and Cindy Scharer for valuable technical assistance. The cost of publishing this paper was defrayed in part by the payment of page charges. Under postal regulations, this paper therefore must be hereby marked advertisement solely to indicate this fact.
Prestorage hot air treatment of apples has promise as a method to reduce storage decay. Exposing 'Golden Delicious' apples to $38^{\circ} \mathrm{C}$ for $4 \mathrm{~d}$ reduced decay caused by Penicillium expansum Link in fruit inoculated after 6 months of storage at $0{ }^{\circ} \mathrm{C}$ (Sams et al., 1993). More recently, decay caused by Botrytis cinerea Pers:Fr. or P. expansum was virtually eliminated in stored 'Golden Delicious' apples heat-treated at $38^{\circ} \mathrm{C}$ after inoculation with the fungus (Fallik et al., 1995; Klein et al., 1997).

Increasing the $\mathrm{Ca}$ concentration of apple flesh by direct postharvest application also reduces postharvest decay caused by $\mathrm{B} . \mathrm{ci}$ nerea, Glomerella cingulata (Stoneman) Spauld. \& Schrenk, and P. expansum (Conway and Sams, 1983; Conway et al., 1991). The Ca concentration necessary to reduce decay in fruit is higher than can be gained with standard fertilization practices. Therefore, direct post- harvest application is the most successful method of achieving the desired concentration (Conway, 1982).

A mechanism proposed for this increased resistance involves the binding of $\mathrm{Ca}$ ions to pectins in the cell wall. Apple fruit cell walls with higher concentrations of $\mathrm{Ca}$ are more resistant to maceration by polygalacturonase produced by $P$. expansum than cell walls lower in $\mathrm{Ca}$ (Conway et al., 1988). Increasing the $\mathrm{Ca}$ content of apples also maintains fruit firmness (Sams and Conway, 1984) and reduces storage disorders, since many of these disorders are related to tissue $\mathrm{Ca}$ concentration (Shear, 1975).

A more recent alternative to the use of postharvest fungicides involves biological control of postharvest pathogens (Janisiewicz, 1988, 1998; Korsten et al., 1994; Wilson and Wisniewski, 1989). Decay caused by B. cinerea and $P$. expansum has been controlled on apples and pears (Pyrus communis L.) by bacterial and yeast antagonists, both under laboratory and large-scale storage tests (ChandGoyal and Spotts, 1996; Janisiewicz and Marchi, 1992; Janisiewicz et al., 1994; Roberts, 1990). Additionally, commercially acceptable levels of control have been achieved in some instances (Janisiewicz and Marchi, 1992; Roberts, 1990). Pseudomonas syringae van Hall (strain ESC-11) is sold commercially under the names BioSave-11 and BioSave110 (EcoScience Corp., Orlando, Fla.), and is currently being used to control decay on apples and pears caused by B. cinerea, Mucor piriformis Fischer, and $P$. expansum (Janisiewicz and Marchi, 1992; Janisiewicz and Jeffers, 1997).

The alternatives to chemical control are generally less effective than many fungicides. The effect of external factors on biological control (performance margin) is generally greater than for fungicides. For example, as fruit mature, higher concentrations of the antagonist must be used to achieve the same level of control as on immature fruit (unpublished data). One of the major problems with using $\mathrm{Ca}$ infiltration as a decay resistance factor has been the inability to predict the amount of $\mathrm{Ca}$ absorbed and the resulting surface discoloration if too much is absorbed (Conway et al., 1994a). While heat treatment virtually eliminates decay if fruit are inoculated prior to heating, it has little effect when applied after inoculation (Klein et al., 1997).

A combination of the above three methods may be more effective than any one alone, and the different methods may complement one another to help minimize the shortcomings of each. Combining heat and $\mathrm{Ca}$ treatments was found to be more effective than either alone under certain circumstances (Conway et al., 1994b; Klein et al., 1997; Sams et al., 1993) and combining Ca infiltration with a biocontrol agent was more effective than the individual treatments alone (Janisiwicz et al., 1998).

The objective of this study was to combine heat treatment, Ca infiltration, and the antagonist $P$. syringae strain ESC-11 to develop an integrated strategy to reduce postharvest decay of 'Gala' apple fruit caused by P. expansum. 


\section{Materials and Methods}

Fruit. 'Gala' apples were harvested on 8 Sept. 1997 in the preclimacteric stage from a commercial orchard in Pennsylvania and randomized prior to treatment. Ethylene production was $<2 \mathrm{pmol} \cdot \mathrm{kg}^{-1} \cdot \mathrm{s}^{-1}$ and the climacteric rise in $\mathrm{CO}_{2}$ production had not yet begun. Firmness was $88.2 \mathrm{~N}$, soluble solids concentration $12.6 \%$, and starch 6.6 as measured by the Cornell Scale of 1 to 8.

Heat treatment. Fruit were placed in traypacked boxes with perforated polyethylene bags as liners and then heated in a thermostatically controlled $\left( \pm 1{ }^{\circ} \mathrm{C}\right)$ walk-in chamber. Apples were heated at $38{ }^{\circ} \mathrm{C}$ for $4 \mathrm{~d}$ and the relative humidity was maintained at $>85 \%$ in the chamber. Storage conditions were monitored with a hygrothermograph (Belfort Instrument Co., Baltimore).

Calcium treatment. 'Gala' apples were pressure-infiltrated ( 3 min at $103 \mathrm{kPa}$ ) with a 0.14 mol $\cdot \mathrm{L}^{-1}$ solution of $\mathrm{CaCl}_{2} \cdot 2 \mathrm{H}_{2} \mathrm{O}$. Following treatment, the fruit were allowed to air-dry and then were either stored immediately at $1{ }^{\circ} \mathrm{C}$ or given further treatment prior to storage. Fruit not heat treated were Ca-infiltrated within $2 \mathrm{~d}$ of harvest. Heat-treated fruit were placed in the heat chamber within $2 \mathrm{~d}$ of harvest, removed after $4 \mathrm{~d}$, allowed to cool to $24{ }^{\circ} \mathrm{C}$ for $\approx 24 \mathrm{~h}$, and then Ca infiltrated.

Total calcium content. Calcium content of the apple tissue at the depth of the inoculation wound was determined by removing the peel and outer flesh of the entire fruit to a depth of $2 \mathrm{~mm}$ with a mechanical peeler. This layer was discarded. The next $2 \mathrm{~mm}$ of flesh was removed, again with the mechanical peeler, and used for analysis. After being removed, the fruit flesh was frozen immediately in liquid $\mathrm{N}_{2}$, freeze-dried, and ground. From each sample, $1 \mathrm{~g}$ of dried material was ashed, dissolved in $5 \mathrm{~mL}$ of $2 \mathrm{~mol} \cdot \mathrm{L}^{-1} \mathrm{HCl}$, and filtered. The samples were then analyzed for $\mathrm{Ca}$ content by inductively coupled plasma emission spectrometry. The flesh from four apples made up one sample and five samples were analyzed for each treatment.

Pathogen. The pathogen used was a very aggressive isolate of $P$. expansum (MD-8) from our collection, which had been previously isolated from a decayed apple in storage. It was maintained on potato-dextrose-agar (PDA) and continued virulence was assured by periodic transfers through apple. The conidial suspension used for fruit inoculations was prepared as previously described (Janisiewicz and Marchi, 1992).

Effect of heat on the pathogen. To determine the direct effect of heat on viability and pathogenicity of $P$. expansum conidia, a 10-dold culture of the pathogen growing on PDA in a petri plate was held at $38^{\circ} \mathrm{C}$. After $24,48,72$, and $96 \mathrm{~h}$, a small section of the culture was removed, the conidia were harvested in sterile distilled water containing $0.05 \%$ Tween-20 (polyoxyethylene sorbitan monolaureate) and the concentration of the conidial suspensions adjusted to either $10^{4}, 10^{5}$, or $10^{6}$ spores $/ \mathrm{mL}$ using a haemocytometer. To determine the viability of the conidia, $0.10 \mathrm{~mL}$ of each of the three conidial concentrations was spread with a glass rod over the surface of PDA plates. The plates were then placed in a $22{ }^{\circ} \mathrm{C}$ incubator and evaluated daily for colony growth. The viability of the conidia was determined by the number of colonies on the plate. Three plates were used per conidial concentration. To determine the effect of heat on pathogenicity, 'Gala' apples which had been in storage at $1{ }^{\circ} \mathrm{C}$ for 6 months were removed, placed at $24{ }^{\circ} \mathrm{C}$ for $\approx 24 \mathrm{~h}$, inoculated with $P$. expansum conidia that had previously been exposed to $38^{\circ} \mathrm{C}$ as above, incubated at $20^{\circ} \mathrm{C}$ for $7 \mathrm{~d}$, and rated for decay as described below. There were three replicates of a single apple per treatment, and each fruit was wounded and inoculated at three sites.

Antagonist. The antagonist used was $P$. syringae isolate ESC-11, which is commercially used in BioSave-11 and BioSave-110. This isolate was grown in $50 \mathrm{~mL}$ of nutrient yeast-dextrose-broth(NYDB) medium in 250$\mathrm{mL}$ Erlenmeyer flasks on a rotary shaker at $150 \mathrm{rpm}$ at $26^{\circ} \mathrm{C}$. Following incubation for 24 $\mathrm{h}$, the cells were harvested by centrifugation at $7000 g_{\mathrm{n}}$ for $10 \mathrm{~min}$, resuspended in water, and the concentration adjusted to $5.4 \times 10^{8} \mathrm{CFU} /$ $\mathrm{mL}$ with a spectrophotometer.

Fruit inoculation. To test the effect of heat on $P$. expansum pathogenicity and host resistance, wounded apples were inoculated with $P$. expansum just prior to heat treatment (38 ${ }^{\circ} \mathrm{C}, 4 \mathrm{~d}$ ). Following heat treatment, fruit were evaluated after incubation at $24^{\circ} \mathrm{C}$ for $7 \mathrm{~d}$ or after 3 and 6 months storage at $1{ }^{\circ} \mathrm{C}$. To determine the effects of the treatment combinations, heat-treated fruit were allowed to cool to $24^{\circ} \mathrm{C}$ and then pressure infiltrated with the Ca solution, allowed to air dry, and placed in storage at $1{ }^{\circ} \mathrm{C}$. A similar inoculation protocol was followed when the fruit were inoculated 3 and 6 months after storage, except that, in some treatments, inoculation with the antagonist preceded inoculation with $P$. expansum conidia. Each apple was wounded twice on the same side by removing a section of tissue 3 $\mathrm{mm}$ in diameter and $3 \mathrm{~mm}$ in depth. One wound was $15 \mathrm{~mm}$ above the equator of the fruit toward the stem end and the other $15 \mathrm{~mm}$ below the equator directly under the first wound. Each wound was inoculated with 25 $\mu \mathrm{L}$ of the $P$. syringae suspension, allowed to air dry $(\approx 1 \mathrm{~h})$, and then inoculated with $20 \mu \mathrm{L}$ of a conidial suspension $\left(5 \times 10^{4}\right.$ conidia $\left./ \mathrm{mL}\right)$ of $P$. expansum. There were 15 fruit per replicate and three replicates per treatment. The fruit were incubated on fruit tray packs in plastic boxes at $24^{\circ} \mathrm{C}$ for $7 \mathrm{~d}$, and the incidence and diameter of the lesions determined. The fruit were arranged in a randomized block design.

Antagonist recovery after heat treatment. The effect of heat on the growth or activity of the antagonist was tested by wound-inoculating the fruit with the antagonist prior to heat treatment at $38^{\circ} \mathrm{C}$. Separate lots of fruit were removed from the heated chamber 24, 48, 72, and 96 $\mathrm{h}$ after inoculation for recovery studies. As a control, a similar lot of fruit was inoculated with the antagonist, placed at $26{ }^{\circ} \mathrm{C}$ and removed after the same times in storage as the heat-treated fruit. Recovery of the antagonist from the wounds was conducted according to the procedure described previously (Janisiewicz, 1996). The colonies on the plates were counted with a Cobanna III laser counter (Spiral Biotech, Bethesda, Md.) after incubation for $24 \mathrm{~h}$ at $24{ }^{\circ} \mathrm{C}$. The counts of CFU per wound were determined using the BEN 4.0 program (Spiral Biotech). There were three fruit with three wounds per fruit for each removal time.

Statistical analysis. Analysis of variance was performed on decay development data using the general linear models procedure (PROC GLM) of the Statistical Analysis System based on type III sums of squares and a randomized complete-block design with factorial treatments (SAS Institute, 1989). The minimum significant differences for separation of the means for the 3 and 6 month data for heat, $\mathrm{Ca}$, antagonist treatments, and their combinations were determined with the Bonferroni (Dunn) $t$ test.

\section{Results}

Effect of heat on the pathogen. Heat treatment of the $P$. expansum culture at $38{ }^{\circ} \mathrm{C}$ reduced conidia survival 10 -fold after only 24 $\mathrm{h}$ and well over 100 -fold after the $96 \mathrm{~h}$ exposure (Fig. 1). During the same time period, there was little change in the viability of the conidia taken from the culture maintained at $22^{\circ} \mathrm{C}$ (data not shown). Pathogenicity of heattreated $P$. expansum conidia on apples decreased and the difference was more apparent on fruit inoculated with lower conidial concentrations (Fig. 2). Exposure to $38{ }^{\circ} \mathrm{C}$ for 96 $\mathrm{h}$ reduced lesion size on fruit inoculated with $10^{4}, 10^{5}$, or $10^{6}$ conidia/mL by $92 \%, 67 \%$, and $25 \%$, respectively. The decline in lesion size with the increasing duration of the heat treatment was more rapid on the fruit inoculated with $10^{4}$ conidia/mL than on those inoculated with $10^{5}$ conidia/mL. Only after $72 \mathrm{~h}$ exposure was there a significant decline in lesion size on fruit inoculated with $10^{6}$ conidia $/ \mathrm{mL}$.

Effect of heat on the antagonist. Heat treatment reduced 10,000-fold the populations of the antagonist, $P$. syringae, in wounds, whereas the populations of the antagonist on apples incubated at $26{ }^{\circ} \mathrm{C}$ over $96 \mathrm{~h}$ were not adversely affected (Fig. 3).

Effect of treatments on lesion size and incidence of decay. Fruit inoculated with $P$. expansum before heat treatment and stored at $20^{\circ} \mathrm{C}$ for $7 \mathrm{~d}$ or at $1{ }^{\circ} \mathrm{C}$ for 3 or 6 months, followed by incubation at $20^{\circ} \mathrm{C}$ for $\approx 24 \mathrm{~h}$, had no decay lesions (Fig. 4). Similarly, no lesions developed on any combination treatment of $P$. expansum, heat, antagonist, or $\mathrm{Ca}$ (data not shown). In comparison, decay lesions of $P$. expansum on inoculated, nonheated fruit were very extensive and difficult to measure accurately after 3 and 6 months in storage, and even though many were over $85 \mathrm{~mm}$ in diameter, they were reported as $\approx 85 \mathrm{~mm}$ (data not shown).

Another lot of heat-treated or control fruit that were either infiltrated or noninfiltrated with $\mathrm{Ca}$ were removed after 3 or 6 months in storage at $1{ }^{\circ} \mathrm{C}$ and inoculated with $P$. expansum 


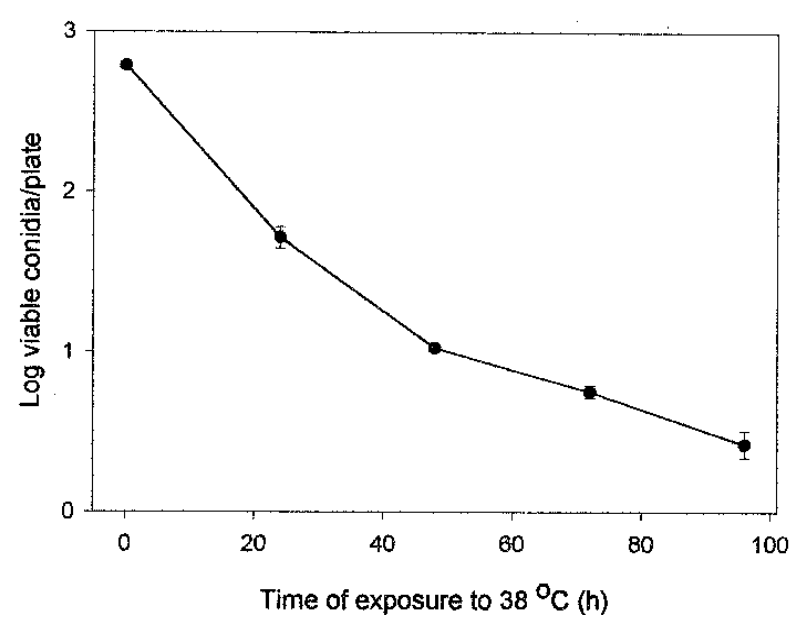

Fig. 1. Effect of heat treatment $\left(38^{\circ} \mathrm{C}\right)$ for various periods of time on the viability of Penicillium expansum conidia. A sporulating culture of $P$. expansum was exposed to $38^{\circ} \mathrm{C}$, after which the conidia were harvested and spread-plated on PDA. Error bars indicate standard error of the means.

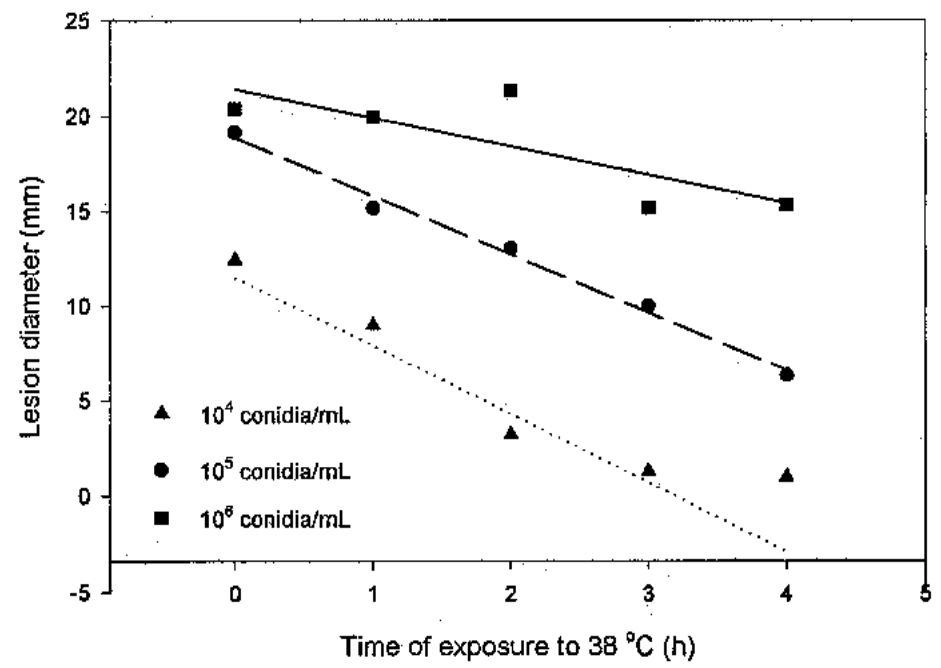

Fig. 2. The effect of heat treatment $\left(38^{\circ} \mathrm{C}\right)$ for various time periods prior to inoculation of fruit on lesion development in 'Gala' apples inoculated with different concentrations of Penicillium expansum conidia. The regression lines were generated from equations: $\mathrm{Y}=11.50-3.06 \mathrm{X}$ with $R^{2}=0.90, P>\mathrm{F}=0.01$, for $10^{4}$ conidial $/ \mathrm{mL} ; \mathrm{Y}=18.90-3.08 \mathrm{X}$ with $R^{2}=0.99, \mathrm{Prob}>\mathrm{F}=0.01$, for $10^{5}$ conidia $/ \mathrm{mL}$; and $\mathrm{Y}=21.43$ $-1.50 \mathrm{X}$ with $R^{2}=0.64, P>\mathrm{F}=0.10$, for $10^{6}$ conidia $/ \mathrm{mL}$

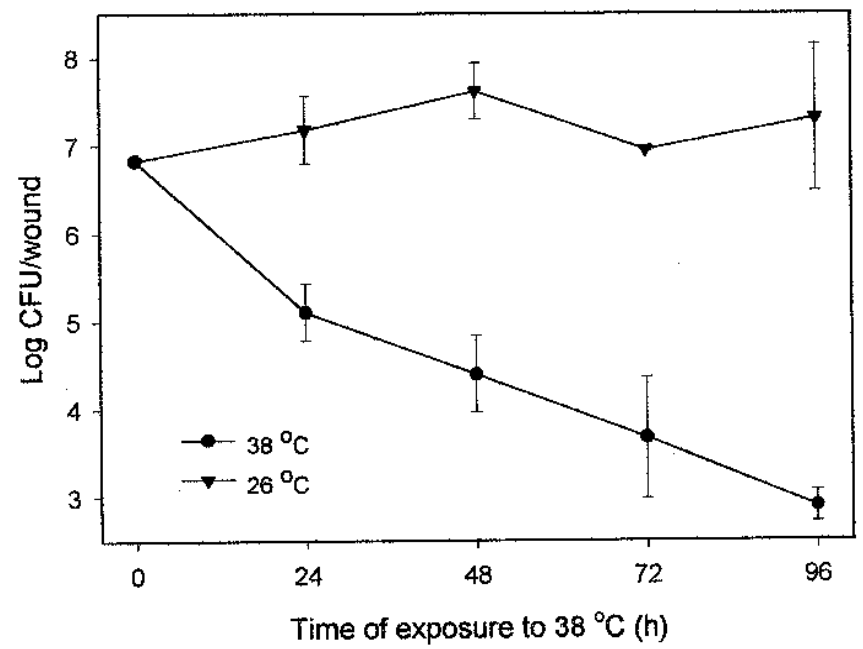

Fig. 3. Effect of temperature on the recovery of the antagonist Pseudomonas syringae isolate ESC11 from wounds in 'Gala' apples. Wounded apples were inoculated with the antagonist and incubated at the indicated temperatures for various periods of time prior to recovery. Error bars indicate standard error of the means $(\mathrm{n}=3)$. only or with the antagonist, $P$. syringae, followed by inoculation with $P$. expansum. Treatments with heat, $\mathrm{Ca}$ or antagonist significantly reduced lesion size and incidence of decay (Table 1). Heat treatment resulted in a significantly greater reduction of decay on antagonist-treated fruit, but not on fruit not treated with the antagonist. Nonheated and heat-treated fruit inoculated with the pathogen alone after 3 months of storage did not differ in incidence of decay. This indicates that heat treatment had little residual effect (Fig. 5A). Ca treatment alone significantly reduced the incidence of decay by $24 \%$. The antagonist alone reduced decay incidence by $40 \%$, which was similar to the $44 \%$ reduction obtained by combining heat and $\mathrm{Ca}$ treatments. Combining heat with the antagonist reduced incidence of decay by $59 \%$, and $\mathrm{Ca}$ plus the antagonist, with and without heat, resulted in a reduction of $98 \%$ and $95 \%$, respectively. Reduction in lesion size also varied considerably with treatment, but a given treatment reduced lesion size and incidence of decay similarly (data not shown).

After 6 months in storage, the relative effectiveness of the various treatments in reducing the incidence of decay and lesion diameter was similar to that for the fruit stored for 3 months. The incidence of decay was just over $90 \%$ for both the nontreated fruit and the heat-treated fruit (Fig. 5). Ca alone, the antagonist alone, and heat plus calcium all reduced the incidence of decay by $\approx 25 \%$, whereas heat plus the antagonist reduced incidence of decay by $70 \%$. Ca plus the antagonist with and without heat treatment reduced decay incidence by $91 \%$ and $89 \%$, respectively. As with incidence of decay, heat treatment did not affect lesion diameter (data not shown).

Calcium concentration in fruit. Infiltration with a $0.14 \mathrm{~mol} \cdot \mathrm{L}^{-1}$ solution of $\mathrm{CaCl}_{2}$ resulted in fruit with a significantly higher $\mathrm{Ca}$ content (46.86 $\mathrm{mmol} \cdot \mathrm{kg}^{-1}$ dry weight) than that of nontreated fruit $\left(8.69 \mathrm{mmol} \cdot \mathrm{kg}^{-1}\right)$ and fruit that were heated before infiltration (37.87 $\left.\mathrm{mmol} \cdot \mathrm{kg}^{-1}\right)$. However, infiltration of heated significantly increased tissue $\mathrm{Ca}$ concentration.

\section{Discussion}

Our results for the effects of heating on fungal conidia germination and the severity of decay on apples inoculated with heated conidia are similar to those of Fallik et al. (1995). They concluded that decay reduction caused by heating of 'Golden Delicious' apples inoculated with $P$. expansum is mainly due to a direct effect of high temperature on the fungus, but that the formation of an anti-fungal substance in the heated peel may also play a role. Decay developed more slowly on heated than on nonheated apples, and almost no decay developed on fruit wounded before heating but inoculated at the end of the heat treatment (Lurie et al., 1998). In our work with apples wounded and inoculated after 3 and 6 months of storage, any antifungal compound may have decreased to ineffective levels, and therefore the residual effect on decay was marginal. 
After both 3 and 6 months in storage, no decay developed on apples that had been inoculated before heat treatment. However, decay lesions on nonheated fruit were extensive and were difficult to measure accurately. Similar results occurred on 'Golden Delicious' fruit inoculated with $B$. cinerea prior to heat treatment (Klein et al., 1997). There was only a marginal residual effect on decay of heat treatment alone if 'Gala' fruit were inoculated 3 or 6 months after storage in our study and little effect on 'Golden Delicious' in previous work (Klein et al., 1997). Prestorage heat treatment of pear fruits at similar temperatures prior to wounding and inoculation with various postharvest pathogens, including $\mathrm{B}$. $\mathrm{ci}$ nerea and $P$. expansum, also did not control decay (Spotts and Chen, 1987).

Heat treatment after inoculation of the wounded fruit with $P$. syringae significantly reduced the population of this antagonist, making it less effective. Since the concentration of the antagonist in these types of wounds must be $\approx 6.0 \times 10^{6} \mathrm{CFU} /$ wound to effectively reduce decay (Janisiewicz and Marchi, 1992), the population of $2.5 \times 10^{4}$ remaining after heat treatment would be ineffective. Control of blue mold with the $P$. syringae antagonist was significantly greater when applied to heated than to nonheated apples. In other work, heat treatment also enhanced the effectiveness of an antagonist, a strain of Pseudomonas glathei Zolg and Ottow, in controlling postharvest decay of oranges caused by Penicillium digitatum Sacc. (Huang et al., 1995). The biocontrol ability of this antagonist was improved greatly when the inoculated fruits were incubated at $30^{\circ} \mathrm{C}$ for $24 \mathrm{~h}$ before being moved to $25^{\circ} \mathrm{C}$. Heat treatment at $30^{\circ} \mathrm{C}$ stimulated the multiplication of the antagonistic bacteria, but retarded spore germination of the pathogen. This allowed the bacteria to become well established at wound sites on fruit before germination of conidia and infection by the pathogen. The heat treatment of apples at $38^{\circ} \mathrm{C}$ for $4 \mathrm{~d}$ was either too long or the temperature too high for biocontrol to occur. A shorter period of heat treatment at higher temperature, however, was less effective in controlling decay of apples (Klein et al., 1997; Lurie et al., 1998).

The exact mechanism by which $P$. syringae reduces decay is not clear, although nutrient/ space competition is a strong possibility (Janisiewicz and Bors, 1995; Janisiewicz and Marchi, 1992). A similar mode of action has been suggested for biocontrol by yeast antagonists on apples (Wilson and Chalutz, 1989). Combining an antagonist with $\mathrm{Ca}$ infiltration may allow lower concentrations of both to be used while still maintaining effective control of decay (Janisiewicz et al., 1998). This can reduce the potential for $\mathrm{Ca}$ injury and may compensate for the declining effectiveness of biocontrol as the fruit mature.

Combining the antagonist treatment with $\mathrm{Ca}$ infiltration reduced the incidence of decay and lesion size more effectively than either treatment alone after 3 and 6 months in storage. This agrees with the results of Janisiewicz et al. (1998) with 'Delicious' apples. Biocontrol of $B$. cinerea and $P$. expansum on apple by two strains of Candida sp. was also enhanced by the addition of $0.14 \mathrm{~mol} \cdot \mathrm{L}^{-1} \mathrm{Ca}$ salts to the antagonist suspension (McLaughlin et al., 1990), which allowed the use of lower concentrations of the antagonist without losing effectiveness. However, in that study the beneficial effect of Ca was attributed to the effect on the antagonists and not on the resistance of fruit to decay.

Development of a strategy which combines several alternative control measures may require a specific treatment order. Since heat treatment negatively affected the antagonist, the antagonist must be applied after heat treatment. Heating very effectively reduces the inoculum level of the pathogen, thereby reducing inoculum pressure and enhancing the control provided by $\mathrm{Ca}$ infiltration or the antagonist. As the inoculum concentration de- creases, the relative effectiveness of cell wallbound Ca in reducing decay increases (Conway et al., 1987), as does the effectiveness of the antagonist, which may allow a lower concentration of the antagonist to be used (Janisiewicz, 1987).

Heating changed the pattern of epicuticular wax in 'Golden Delicious' apples (Lurie et al., 1996; Roy et al., 1994). The epicuticular wax of heat-treated fruit did not have the same network of deep cracks observed on nonheated fruit. This apparent obstruction of the cracks due to a possible recrystallization or 'melting' of the wax platelets hinders infiltration of $\mathrm{CaCl}_{2}$ into the fruit. Heating 'Gala' fruit reduced subsequent infiltration of $\mathrm{CaCl}_{2}$. These results suggest that fruit should be treated with $\mathrm{Ca}$ prior to heat treatment so more Ca solution can enter the fruit. However, Ca infiltration followed by heating resulted in Ca injury at a $\mathrm{Ca}$ concentration much lower than that which would injure non-heat-treated fruit (Conway et al., 1994b). Thus, Ca infiltration should follow heat treatment to reduce the possibility of injury. Fruit tissue Ca concentration can be increased to sufficient levels by infiltration following heat treatment (Klein et al., 1997; Roy et al., 1994).

The presence of $\mathrm{Ca}$ did not negatively affect the populations of the antagonist (Janisiewicz et al., 1998). Therefore, the antagonist can be applied to the fruit immedi-

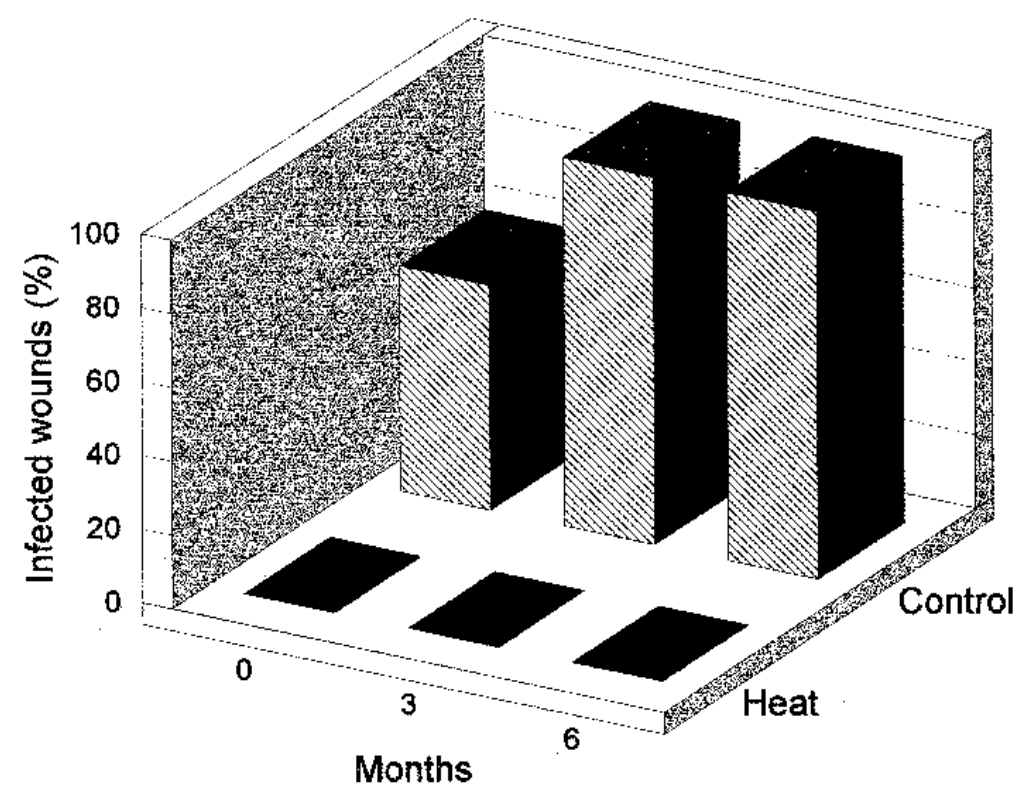

Fig. 4. Effect of heat treatment $\left(38^{\circ} \mathrm{C}, 4 \mathrm{~d}\right)$ on incidence of decay caused by Penicillium expansum in 'Gala' apples after storage for 0,3 , or 6 months. Fruit were inoculated with the pathogen before heat treatment.

Table 1. Summary of the significant effects of heat treatment (inoculated after storage), Ca infiltration, storage duration (months), and antagonist (antag) and pathogen inoculation on lesion size and incidence of decay on 'Gala' apples after storage at $1^{\circ} \mathrm{C}$ for 3 and 6 months.

\begin{tabular}{|c|c|c|c|c|c|c|c|c|}
\hline \multirow[b]{2}{*}{ Source } & \multicolumn{4}{|c|}{ Lesion size } & \multicolumn{4}{|c|}{ Decay incidence } \\
\hline & $\overline{\mathrm{df}}$ & Mean square & F value & $P>\mathrm{F}$ & df & Mean square & F value & $P>\mathrm{F}$ \\
\hline$\overline{\text { Heat }}$ & 1 & 0166.76 & 5.27 & 0.0218 & 1 & 2.68 & 18.63 & 0.0001 \\
\hline $\mathrm{Ca}$ & 1 & 24820.48 & 784.35 & 0.0001 & 1 & 44.95 & 312.17 & 0.0001 \\
\hline Antag & 1 & 36417.36 & 1150.82 & 0.0001 & 1 & 94.43 & 659.36 & 0.0001 \\
\hline Heat $\times$ antag & 1 & 0122.14 & 3.86 & 0.0497 & 1 & 0.64 & 4.47 & 0.0347 \\
\hline $\mathrm{Ca} \times$ antag & 1 & 4437.18 & 140.22 & 0.0001 & 1 & 0.52 & 3.60 & 0.0581 \\
\hline Month $\times$ heat $\times$ antag & 1 & 0230.02 & 7.27 & 0.0071 & 1 & 0.97 & 6.75 & 0.0095 \\
\hline Heat $\times \mathrm{Ca} \times$ antag & 1 & 0468.02 & 14.79 & 0.0001 & 1 & 1.97 & 13.64 & 0.0002 \\
\hline
\end{tabular}


ately after $\mathrm{Ca}$ treatment. Since $\mathrm{Ca}$ is applied to apples in a solution under pressure and the antagonist is applied as a spray under commercial conditions, the antagonist should be applied following $\mathrm{Ca}$ infiltration to prevent it from being washed from the fruit.

Most postharvest pathogens are present on the fruit surface during harvest, but cause decay only after the tissue is wounded or softens sufficiently to permit pathogen penetration and infection. While heat treatment is phytosanitary in that it significantly reduces the pathogen population on the fruit surface and the possibility of infiltration of conidia into the fruit, it provides little residual protection. The residual protection provided by $\mathrm{Ca}$ and the antagonist adds to the control provided by the heat treatment. Ca not only protects the cell wall from maceration by pectic enzymes produced by the fungus, but also maintains fruit firmness and reduces physiological maladies as well. The presence of the antagonist complements this residual Ca resistance. The strategy of heat-treating fruit, followed by $\mathrm{Ca}$ infiltration and then treatment with an antagonist may be a useful alternative to fungicides for postharvest control of decay.

\section{Literature Cited}

Chand-Goyal, T. and R.A. Spotts. 1996. Control of postharvest pear diseases using natural saprophytic yeast colonists and their combination with a low dosage of thiabendazole. Postharvest Biol. Technol. 7:51-64.

Conway, W.S. 1982. Effect of postharvest calcium treatment on decay of Delicious apples. Plant Dis. 66:402-403.

Conway, W.S., K.C. Gross, C.D. Boyer, and C.E. Sams. 1988. Inhibition of Penicillium expansum polygalacturonase activity by increased apple cell wall calcium. Phytopathology 78:10521055.

Conway, W.S., K.C. Gross, and C.E. Sams. 1987. Relationship of bound calcium and inoculum concentration to the effect of postharvest calcium treatment on decay of apples by Penicillium expansum. Plant Dis. 71:78-80.

Conway, W.S. and C.E. Sams. 1983. Calcium infiltration of Golden Delicious apples and its effect on decay. Phytopathology 73:1068-1071.

Conway, W.S., C.E. Sams, J.A. Abbott, and B.D. Bruton. 1991. Postharvest calcium treatment provides broad-spectrum protection against postharvest pathogens. Plant Dis. 75:620-622.

Conway, W.S., C.E. Sams, G.A. Brown, W.S. Beavers, R.B. Tobias, and L.S. Kennedy. 1994a. Pilot test for the commercial use of postharvest pressure infiltration of calcium into apples to maintain fruit quality in storage. HortTechnology 4:239-243.

Conway, W.S., C.E. Sams, C.Y. Wang, and J.A. Abbott. 1994b. Additive effects of postharvest calcium and heat treatment on reducing decay and maintaining quality in apples. J. Amer.Soc. Hort. Sci. 119:49-53.

Fallik, E., S. Grinberg, M. Gambourg, and S. Lurie. 1995. Prestorage heat treatment reduces pathogenicity of Penicillium expansum in apple fruit. Plant Path. 45:92-97.

Huang, Y., B.J. Deverall, and S.C. Morris. 1995. Postharvest control of green mold on oranges by a strain of Pseudomonas glathei and enhance-

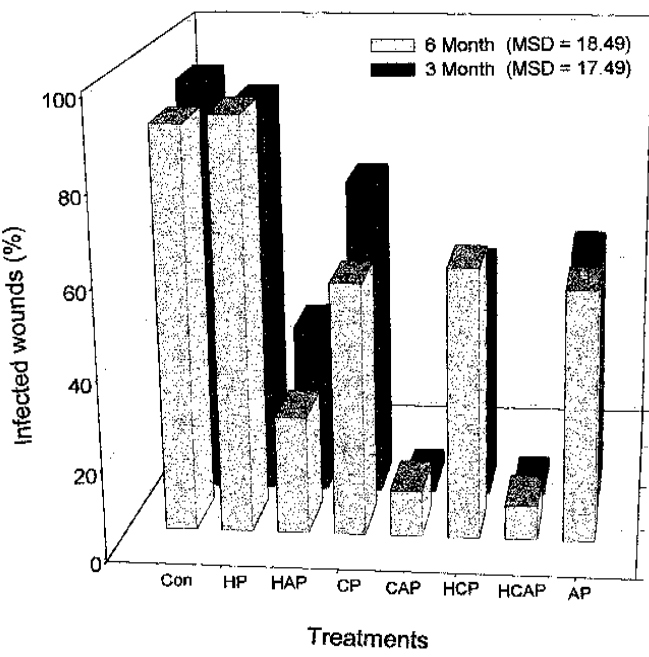

Fig. 5. The effects of heat treatment $(\mathrm{H})$, calcium infiltration $(\mathrm{C})$, antagonist application (A), and combinations thereof on incidence of decay of 'Gala' apples by Penicillium expansum (P). After heat treatment followed by calcium infiltration, the fruit were stored for 3 or 6 months at $1{ }^{\circ} \mathrm{C}$. After removal from storage, the fruit were placed at $24{ }^{\circ} \mathrm{C}$, wounded, and then inoculated with $P$. expansum alone or with the antagonist and $P$. expansum. Fruit were evaluated for incidence of decay $7 \mathrm{~d}$ after inoculation. Con indicates nontreated fruit.

ment of its biocontrol by heat treatment. Postharvest Biol. Technol. 5:129-137.

Janisiewicz, W.J. 1987. Postharvest biological control of blue mold on apples. Phytopathology 77:481-485.

Janisiewicz, W.J. 1988. Biological control of diseases of fruits, p. 153-165. In: K.G. Mukerji and K.L. Garg (eds.). Biocontrol of plant diseases. vol. 2. CRC Press, Boca Raton, Fla.

Janisiewicz, W.J. 1996. Ecological diversity, niche overlap, and coexistence of antagonists used in developing mixtures for biocontrol of postharvest diseases of apples. Phytopathology 86:473-479.

Janisiewicz, W.J. 1998. Biocontrol of postharvest diseases of temperate fruits, p. 171-198. In: G.J. Boland and L.D. Kuykendall (eds.). Plantmicrobe interactions and biological control. Marcel Dekker, New York.

Janisiewicz, W.J. and B. Bors. 1995. Development of a microbial community of bacterial and yeast antagonists to control wound-invading postharvest pathogens of fruits. Appl. Environ. Microbial. 61:3261-3267.

Janisiewicz, W.J., W.S. Conway, D.M. Glenn, and C.E. Sams. 1998. Integrating biological control and calcium treatment for controlling postharvest decay of apples. HortScience 33:105-109.

Janisiewicz, W.J. and S.N. Jeffers. 1997. Efficacy of commercial formulation of two biofungicides for control of blue mold and gray mold of apples in cold storage. Crop Protection 16:629-633.

Janisiewicz, W.J. and A. Marchi. 1992. Control of storage rots on various pear cultivars with a saprophytic strain of Pseudomonas syringae. Plant Dis. 76:555-560.

Janisiewicz, W.J., D.L. Peterson, and B. Bors. 1994 Control of storage decay of apples with Sporobolomyces roseus. Plant Dis. 78:466-470.

Klein, J.D., W.S. Conway, B.D. Whitaker, and C.E. Sams. 1997. Botrytis cinerea decay in apples is inhibited by postharvest heat and calcium treatments. J. Amer. Soc. Hort. Sci. 122:91-94.

Korsten, L., E.E. De Villiers, F.C. Sehner, and J.M. Kotze. 1994. A review of biological control of postharvest diseases of subtropical fruits, $\mathrm{p}$. 172-185. In: B.R. Champ, E. Highley, and G.L. Johnson (eds.). Postharvest handling of tropical fruits. ACIAR Proc. 50.
Lurie, S., E. Fallik, and J.D. Klein. 1996. The effect of heat treatment on apple epicuticular wax and calcium uptake. Postharvest Biol. Technol. 8:271-277.

Lurie, S., E. Fallik, J.D. Klein, F. Kozar, and K. Kovacs. 1998. Postharvest heat treatment of apples to control San Jose scale (Quadraspidiotus perniciosus Comstock) and blue mold (Penicillium expansum Link) and maintain fruit firmness. J. Amer. Soc. Hort Sci. 123:110-114.

McLaughlin, R.J., M.E. Wisniewski, C.L. Wilson, and E. Chalutz. 1990. Effect of inoculum concentration and salt solution on biological control of postharvest diseases of apple with Candida species. Phytopathology 80:456-461.

Roberts, R.G. 1990. Postharvest biological control of gray mold of apple by Cryptococcus laurentii. Phytopathology 80:526-530.

Roy, S., W.S. Conway, A.E. Watada, C.E. Sams, E.F. Erbe, and W.P. Wergin. 1994. Heat treatment affects epicuticular wax structure and postharvest calcium uptake in 'Golden Delicious' apples. HortScience 29:1056-1058.

Sams, C.E. and W.S. Conway. 1984. Effect of calcium infiltration on ethylene production, respiration rate, soluble polyuronide content, and quality of 'Golden Delicious' apple fruit. J. Amer. Soc. Hort. Sci. 109:623-627.

Sams, C.E., W.S. Conway, J.A. Abbott, R.J. Lewis, and N. Ben-Shalom. 1993. Firmness and decay of apples following postharvest pressure infiltration of calcium and heat treatment. J. Amer. Soc. Hort. Sci. 118:623-627.

SAS Institute. 1989. SAS/STAT user's guide, ver. 6, vol. 2, 4th ed. SAS Inst., Cary, N.C.

Shear, C.B. 1975. Calcium related disorders of fruits and vegetables. HortScience 10:361-365.

Spotts, R.A. and P.M. Chen. 1987. Prestorage heat treatment for control of decay of pear fruit. Phytopathology 77:1578-1582.

Wilson, C.L. and E. Chalutz. 1989. Postharvest biological control of Penicillium rots of citrus with antagonistic yeasts and bacteria. Scientia Hort. 40:105-112.

Wilson, C.L. and M.E. Wisniewski. 1989. Biological control of postharvest diseases of fruits and vegetables: An emerging technology. Annu. Rev. Phytopathol. 27:425-441. 